\title{
CHRONOLOGY OF THE EARLY PRE-POTTERY NEOLITHIC SETTLEMENT TELL QARAMEL, NORTHERN SYRIA, IN THE LIGHT OF RADIOCARBON DATING
}

\author{
Ryszard F Mazurowski ${ }^{1}$ Danuta J Michczyńska² Anna Pazdur $^{2}$ - Natalia Piotrowska² \\ ABSTRACT. Archaeological excavations at the Syrian settlement of Tell Qaramel have been conducted since 1999. They \\ are concentrated on remnants of the Protoneolithic and early stages of the Pre-Pottery Neolithic period. The settlement has \\ revealed an extremely rich collection of everyday use of flint, bone, and mostly stone objects, such as decorated chlorite or \\ limestone vessels; shaft straighteners used to stretch wooden arrow shafts, richly decorated in geometrical, zoomorphic, and \\ anthropomorphic patterns; as well as different kinds of stones, querns, mortars, pestles, grinders, polishing plates, celts, and \\ adzes.
}

Excavations brought the discovery of 5 circular towers. Some 57 charcoal samples were collected during the excavations and dated in the GADAM Centre in Gliwice, Poland. The stratigraphy of the settlement and results of radiocarbon dating testify that these are the oldest such constructions in the world, older than the famous and unique tower in Jericho. They confirm that the Neolithic culture was formed simultaneously in many regions of the Near East, creating a farming culture and establishing settlements with mud and stone architecture and creating the first stages of a proto-urban being.

\section{INTRODUCTION}

Methods of probabilistic calibration and interpretation of radiocarbon dates (Buck et al. 1991; Bronk Ramsey 1995, 2001) were used to study the cultural periodization of Tell Qaramel, Syria. Archaeological excavations were conducted in the framework of an international project, led since 1999 by the Syrian-Polish Archaeological Mission, codirected by Prof Ryszard F Mazurowski and Dr Yousef Kanjou, which has performed an intensive archaeological excavation of a large ( $3.5 \mathrm{ha})$ settlement that had been occupied during the Protoneolithic and Early Pre-Pottery Neolithic periods (Mazurowski 2000, 2003, 2004, 2005, 2006, 2009a; Mazurowski and Jamous 2001; Mazurowski and Yartah 2002; Mazurowski and Kanjou 2009). The settlement existed between 10,900 and 8800 BP. It should be noted that more recent, deeper excavations have revealed even older layers that appear to belong to the Early Epipaleolithic. In 3 excavated squares below the oldest layer of horizon H1 (Protoneolithic culture) - below a 30- to 40-cm-thick layer of natural flooded mud without any traces of human activity-remnants of the oldest occupation on the site have been found. The discoveries included a circular dwelling, hearths and pits, as well as a collection of 21 massive flint flakes representing different cultures contemporary to horizon H0. It is very possible that with this above-mentioned horizon, the 4 oldest ${ }^{14} \mathrm{C}$ dates are associated (see Figure 2). The technology of flint knapping observed on the base of the flake collection shows fundamental differences to materials very well known from the Protoneolithic horizon H1.

\section{SITE}

The settlement Tell Qaramel is located in the so-called Fertile Crescent (see Figure 1), a historical crescent-shaped region in the Middle East that has an impressive record of past human activity. The term was coined by J H Breasted, founder of the Oriental Institute at the University of Chicago (http: //oi.uchicago.edu/museum/east; Kozlowski 1999). This region includes many sites with skeletal and cultural remains of both pre-modern and early modern humans. This area is most unique for its sites related to the origins of agriculture (Braidwood et al. 1983; Kozlowski 1998, 1999).

\footnotetext{
${ }^{1}$ Institute of Archaeology, Warsaw University, Krakowskie Przedmiescie 26/28, 00-927 Warsaw, Poland. Corresponding author. Email: mazurowscy@acn.waw.pl.

${ }^{2}$ GADAM Centre of Excellence, Institute of Physics, Silesian University of Technology, Krzywoustego 2, 44-100 Gliwice, Poland.
}

(C) 2009 by the Arizona Board of Regents on behalf of the University of Arizona

Proceedings of the 5th International ${ }^{14} \mathrm{C}$ and Archaeology Symposium, edited by Irka Hajdas et al.

RADIOCARBON, Vol 51, Nr 2, 2009, p 771-781 


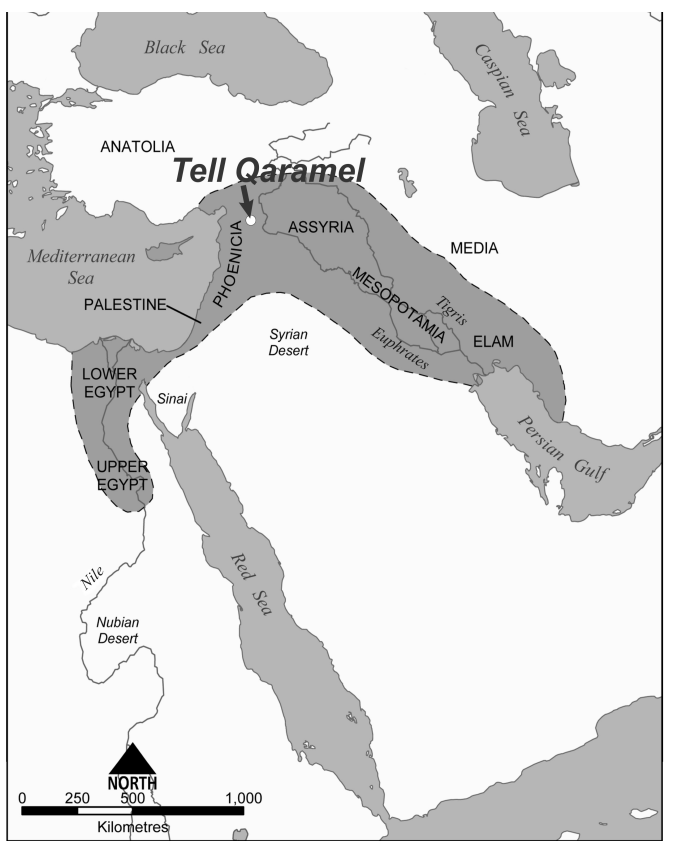

Figure 1 The Fertile Crescent with the location of Tell Qaramel marked (source of map: http://en.wikipedia.org/wiki/ Image:Fertile_Crescent_map.png).

This site, in the current village of Qaramel, is located in the basin of the River Qoueiq, about $25 \mathrm{~km}$ north of Aleppo and $65 \mathrm{~km}$ south of the Syrian-Turkish border and Taurus Mountains. The northeastern part includes the prehistoric settlement, adjacent to the western bank of the river, and is covered by an ovoidal $(190 \times 160 \mathrm{~m})$ tell built by remnants of occupations from the Protoneolithic, Early Pre-Pottery Neolithic (PPNA), to the Ottoman period. This settlement appears to have been very well situated from an economic point of view as the Qoueiq River valley contains soils of the highest quality for agricultural purposes, the so-called "red soils." The site also must have had considerable exposure to commercial activity, which still exists as indicated by the presence along the river of the "Silver Road" connecting the Near East and Egypt with Anatolia, central Asia, and the Far East.

The excavated Protoneolithic and Early Pre-Pottery Neolithic settlement at Qaramel, the first such site known from the northern Levant, developed during an early stage in the formation of new cultural and economic models of civilization. The growing specialization in the gathering of wild fruits and cereals must have contributed to the domestication of fruit, wheat, and barley just as the parallel specialization in hunting must have led to domestication of sheep and goats, and later also of cattle and pigs (Mellaart 1975; Cauvin 1997; Aurenche and Kozlowski 1999; Kozlowski and Aurenche 2005; Willcox 2005). Consequently, during later millennia, as these developments expanded into Europe and many regions of the Middle East and Asia, they shaped an entire model of culture typical for the Old World. However, it is very important to add that professional examination of paleobotanical and archeozoological remains from Proto- and Pre-Pottery Neolithic layers of the Qaramelian settlement gave us very surprising results. In the opinion of archaeozoologist A Grezak (2009: 96-103), in the more than 45,000 complete and fragments of animal bones taken from all horizons of occupation there are no traces of domestication of animals. Also, Willcox and Herveux (2009; 
Willcox et al. 2008) after examination by flotation of 108 samples (1772 L) of sediment mostly representing horizons $\mathrm{H} 2, \mathrm{H} 3$, and some of $\mathrm{H} 1$, they conclude "Compared to the Euphrates, at Tell Qaramel the cereals could have been growing locally, so there would have been less incentive to cultivate. It can be assumed that the majority of the plant resources were gathered rather than cultivated. However we should not exclude the possibility that some cultivation was taking place" (Willcox and Herveux 2009:11). In Mazurowski's opinion, paleobotanical examination above described does not give us direct evidence of cultivation cereals by inhabitants of Qaramel village during horizons $\mathrm{H} 1-\mathrm{H} 3$ (from $\mathrm{H} 4$ there is a lack of samples because the youngest layers are mostly destroyed by Bronze and Iron Age occupation). Inhabitants of Tell Qaramel (gatherers and hunters!) over a long period of time $(10,890-8780 \mathrm{cal}$ BC) created a very high developed Protoneolithic and Pre-Pottery Neolithic A culture with an extremely developed specialization in gathering of plants and hunting. Qaramelian settlement was located in a very favorable environment with many local plants used for consumption (Willcox and Herveux 2009). This is confirmed by the rich collection of grains and spikelet bases of cereals [Triticum boeticum (1410 pieces), Triticum/Secale (1170), Triticum diccocum (4), and Hordeum spontaneum (217)]. Edible pulses [Lens (1113); Pisum/Vicia/ Lathyrus, Vicia (712)] and edible fruits [Pistacia (1769), Celtis (400), Amygdalus (2214)] were also important elements in the diet. In the light of the Qaramel settlement economy described above, the problem remains of which criteria to use to determine the settlement's Neolithization. In fact, this high developed culture - very "neolithic" in many fundamental aspects — was based on an "Epipaleolithic" economy of very specialized gatherers and hunters.

\section{MATERIALS AND METHODS}

The Tell Qaramel site includes 5 of the oldest rounded towers in the world, 2 spectacular shrines (one also was a kind of common house for meetings), more than 60 circular and oval houses along with accompanying utility buildings divided in 14 occupational levels Mazurowski (2009a). The remains of the mentioned occupational levels were finally sorted into 5 chronological horizons ( $\mathrm{H} 0$ $\mathrm{H} 4)$. In addition to the houses, there are hearths, storage and waste pits, and hiding places in the courtyards, as well as numerous pit graves with deceased lying in the fetal position. The houses were partly dug into the ground or most often were built directly on the ground, with walls from irregular blocks or pecine mud mixed with fine stone pebbles, bones, and all sorts of other materials present in the surroundings.

The 14 occupational levels, concentrated in several trenches (squares) of about 6.0 ha in area, have been correlated, taking into the account the stratigraphic context of particular features, their character, and association with flint, stone, bone, and clay objects, as well as types of houses and methods of construction. Finally, the results of the archaeological research were confirmed by ${ }^{14} \mathrm{C}$ dating. Mazurowski (2009a; Mazurowski et al. 2009) described the occupation/architectural levels as representing a sequence of continuous, gradual, and evolutionary transformations in urban planning, architecture, material culture, ideology, and also in terms of funerary rituals and art. It is also necessary to note that in Tell Qaramel sequence the Proto- and Pre-Pottery Neolithic layers that are $2.6 \mathrm{~m}$ or greater in thickness do not show any breaks or discontinuity in occupation. Moreover, a very fluent transformation from the Protoneolithic to Pre-Pottery Neolithic is evident. Thus, Mazurowski (2009a) decided to give up on the separating traditional phases and instead created 5 horizons of occupation (H0-H4), which in some general aspects can correspond with periodization of development of the Protoneolithic and Pre-Pottery Neolithic cultures in the Near East. From an archaeological point of view, in the Tell Qaramel settlement there is no possibility to show distinctive borders between horizons, which is also observed on the curve of summed probability distribution of ${ }^{14} \mathrm{C}$ dates for particular horizons (see Figures 2 and 3; Table 1). 
Despite the visible evolution in the construction techniques, the final stage of horizon $\mathrm{H} 3$ the first rectangular houses were beginning to be built. A very rich collection of tools, ornaments, and objects of art has been obtained from layers and fills of the houses. Some 351(!) specimens have been decorated or represent complete or fragments of human (2) and zoomorphic sculptures. There is also a very rich collection of wonderfully decorated shaft straighteners, bowls of Jerf el-Ahmar type, fragments of everyday activity tools (pestles, pointed tools, awls, celts, chisels), and ornaments (pendants, discs, rings, plaquettes) (Mazurowski 2009b). Nearly all of them were made of chlorite pebbles and very rarely of limestone and mudstone. Two soft, white limestone human figurines show some similarities to specimens known from Jerycho, Mureybet III, Gilgal I, Nahal Hemar, Nevali Çori, Jerf el-Ahmar (Mellaart 1975: Figure 16; Kozlowski and Aurenche 2005:210, Figures 6.6.1, 6.3.3). Naturalistic zoomorphic figurines are represented by stone figurines of snake, catfish, an animal hoof, and 1 complete and 1 fragment of bird heads with a massive beak and neck. Another 2 fragments of birds were made of sun-dried clay. Stone shaft straighteners were decorated by engraving, grooving, notching, and drilling. More than $80 \%$ were estimated to have been decorated. After geometric decoration, the most common motifs are naturalistic or schematic, combining zoomorphic and anthropomorphic images. The most common design has 1 or more snakes, followed by birds, a turtle and porcupine killed by arrows, a gazelle with snakes, a panther ready to leap, solar and lunar motifs, human figures surrounded by trees, and human figures dancing(?) (Mazurowski 2009b).

Some 57 charcoal and 12 carbonate samples were collected during excavations in 2001-2005. In this study, we use only charcoal samples due to the difficulties in interpreting ${ }^{14} \mathrm{C}$ ages of the carbonate binders from mortars (e.g. Van Strydonck et al. 1986; Heinemeier et al. 1997; Sonninen and Jungner 2001; Hodgins et al. 2006; Nawrocka et al. 2005; Michalska-Nawrocka et al. 2007).

All samples were dated in the Gliwice Radiocarbon Laboratory. After chemical pretreatment (AAA) and carbonization, the samples were combusted, and $\mathrm{CO}_{2}$ was purified by the standard method used in the Gliwice Radiocarbon Laboratory (Pazdur and Pazdur 1986). Finally, ${ }^{14} \mathrm{C}$ activity measurements were carried out by conventional techniques, GPC or LSC (Pazdur et al. 2000, 2003). Two samples were dated using accelerator mass spectrometry (AMS) (Goslar and Czernik 2000; Piotrowska and Goslar 2002). The ${ }^{14} \mathrm{C}$ dating results are given as measured ${ }^{14} \mathrm{C}$ ages $T$ with uncertainty $\Delta T(T \pm \Delta T)$. According to the commonly accepted convention (Stuiver and Polach 1977), the $\Delta T$ value is calculated only on the basis of statistical analysis of the measurements and properties of the apparatus without taking into account any extralaboratory factors.

There are 2 commonly used calibration programs, BCal (http://bcal.shef.ac.uk/) and OxCal (https:// c14.arch.ox.ac.uk/oxcal/), which allow including a priori information. All analysis presented in this paper was carried out with the program OxCal v. 4.05 (Bronk Ramsey 1995, 2001).

\section{RESULTS}

A preliminary chronology of the Tell Qaramel settlement was established following archaeological stratigraphy and cultural remains, and later fixed on the basis of $57{ }^{14} \mathrm{C}$ dates of charcoal samples (see Table 1). ${ }^{14} \mathrm{C}$ dating results show the occupation and evolution of the settlement from the early stages of the Pre-Pottery Neolithic period, which covers about 10,900-8800 BC (see Figure 2).

Table 1 Results of ${ }^{14} \mathrm{C}$ dating of 57 charcoal samples from the site Tell Qaramel.

\begin{tabular}{llll}
\hline Sample name, lab code & ${ }^{14}$ C age (BP) & Comments & Horizon \\
\hline QRM 2056/13, Gd-12802 & $11,420 \pm 130$ & Date for Epipaleolithic occupation in H0(?) & 0 \\
QRM 651/8, Gd-17124 & $11,900 \pm 610$ & Date for Epipaleolithic occupation in H0(?) & 0 \\
QRM 1202, Gd-18296 & $14,190 \pm 210$ & Date for Early Epipaleolithic occupation in H0(?) & 0
\end{tabular}


Table 1 Results of ${ }^{14} \mathrm{C}$ dating of 57 charcoal samples from the site Tell Qaramel. (Continued)

\begin{tabular}{|c|c|c|c|}
\hline Sample name, lab code & ${ }^{14} \mathrm{C}$ age $(\mathrm{BP})$ & Comments & Horizon \\
\hline QRM 1206, Gd-17293 & $15,020 \pm 280$ & Date for Early Epipaleolithic occupation in $\mathrm{HO}(?)$ & 0 \\
\hline QRM 1445, Gd-12649 & $9830 \pm 100$ & $\begin{array}{l}\text { Date too early for one of the oldest layers in the } \\
\text { site }\end{array}$ & 1 \\
\hline QRM 918/18, Gd-12510 & $10,015 \pm 90$ & A little too late for his horizon & 1 \\
\hline QRM 1444, Gd-12651 & $10,080 \pm 90$ & A little too late for this oldest layer of $\mathrm{H} 1$ & 1 \\
\hline QRM 919/20, Gd-17249 & $10,170 \pm 280$ & In accordance with archaeological data & 1 \\
\hline QRM 949/25, Gd-15486 & $10,220 \pm 140$ & In accordance with archaeological data & 1 \\
\hline QRM 1324, Gd-15676 & $10,230 \pm 120$ & In accordance with archaeological data & 1 \\
\hline QRM 948/9, Gd-12503 & $10,245 \pm 95$ & In accordance with archaeological data & 1 \\
\hline QRM 1468, Gd-12639 & $10,250 \pm 80$ & In accordance with archaeological data & 1 \\
\hline QRM 1443, Gd-15681 & $10,280 \pm 150$ & In accordance with archaeological data & 1 \\
\hline QRM 993/14, Gd-11673 & $10,280 \pm 90$ & In accordance with archaeological data & 1 \\
\hline QRM 893/21, Gd-12514 & $10,310 \pm 130$ & In accordance with archaeological data & 1 \\
\hline QRM 650/6, Gd-18038 & $10,320 \pm 440$ & In accordance with archaeological data & 1 \\
\hline QRM 958/19, Gd-12506 & $10,360 \pm 95$ & In accordance with archaeological data & 1 \\
\hline QRM 988/15, Gd-12515 & $10,510 \pm 95$ & In accordance with archaeological data & 1 \\
\hline QRM 1990/14, Gd-12799 & $10,620 \pm 120$ & In accordance with archaeological data & 1 \\
\hline QRM 1442, Gd-11741 & $10,680 \pm 60$ & In accordance with archaeological data & 1 \\
\hline QRM 1398, Gd-15679 & $10,700 \pm 140$ & In accordance with archaeological data & 1 \\
\hline QRM 1275, Gd-12638 & $7370 \pm 80$ & Aberration & 2 \\
\hline QRM 925/11, Gd-15477 & $8860 \pm 110$ & Aberration & 2 \\
\hline QRM 612/3, Gd-30006 & $9120 \pm 230$ & Aberration & 2 \\
\hline QRM 2078/5, GdS-359 & $9710 \pm 70$ & $\begin{array}{l}\text { Date too late for tower IV. Probably date of fire } \\
\text { damaging first phase of tower IV(?); sample also } \\
\text { corresponds well with tower V dates }\end{array}$ & 2 \\
\hline QRM 647/4, Gd-30007 & $9850 \pm 160$ & In accordance with archaeological data & 2 \\
\hline QRM 1882/11, Gd-12819 & $9950 \pm 110$ & In accordance with archaeological data & 2 \\
\hline QRM 1975/2, GdS-364 & $9980 \pm 70$ & In accordance with archaeological data & 2 \\
\hline QRM 524/1, Gd-30004 & $9990 \pm 120$ & In accordance with archaeological data & 2 \\
\hline QRM 646/5, Gd-18036 & $10,040 \pm 460$ & Acceptable, large laboratory uncertainty & 2 \\
\hline QRM 1325, Gd-12652 & $10,090 \pm 100$ & In accordance with archaeological data & 2 \\
\hline QRM 653/7, Gd-18035 & $10,130 \pm 540$ & Acceptable, large laboratory uncertainty & 2 \\
\hline QRM 894/13, Gd-12502 & $10,140 \pm 110$ & In accordance with archaeological data & 2 \\
\hline QRM 920/12, Gd-11627 & $10,170 \pm 70$ & In accordance with archaeological data & 2 \\
\hline QRM 1843/7, Gd-12811 & $10,180 \pm 110$ & In accordance with archaeological data & 2 \\
\hline QRM 652/2, Gd-30005 & $10,295 \pm 85$ & In accordance with archaeological data & 2 \\
\hline QRM 926/10, Gd-12504 & $10,350 \pm 120$ & In accordance with archaeological data & 2 \\
\hline QRM 1399, Gd-30062 & $10,360 \pm 80$ & $\begin{array}{l}\text { Date too early for this horizon of occupation; } \\
\text { aberration (?) }\end{array}$ & 2 \\
\hline QRM 2091/6, Gd-12797 & $10,440 \pm 120$ & In accordance with archaeological data & 2 \\
\hline QRM 921/24, Gd-15502 & $7490 \pm 185$ & Aberration & 3 \\
\hline QRM 1172, Gd-12637 & $8220 \pm 100$ & Aberration & 3 \\
\hline QRM 1422, GdA-467 & $8370 \pm 90$ & Aberration & 3 \\
\hline QRM 1928/16, Gd-12817 & $9420 \pm 100$ & Too late for this horizon & 3 \\
\hline QRM 2059/15, GdS-360 & $9520 \pm 70$ & In accordance with archaeological data & 3 \\
\hline QRM 1964/1, GdS-363 & $9550 \pm 65$ & In accordance with archaeological data & 3 \\
\hline QRM 2068/9, GdS-358 & $9640 \pm 60$ & In accordance with archaeological data & 3 \\
\hline QRM 2067/8, GdS-361 & $9770 \pm 110$ & In accordance with archaeological data & 3 \\
\hline QRM 2066/12, GdS-362 & $9840 \pm 70$ & In accordance with archaeological data & 3 \\
\hline QRM 1379, GdA-466 & $9850 \pm 110$ & In accordance with archaeological data & 3 \\
\hline
\end{tabular}


Table 1 Results of ${ }^{14} \mathrm{C}$ dating of 57 charcoal samples from the site Tell Qaramel. (Continued)

\begin{tabular}{lrll}
\hline Sample name, lab code & ${ }^{14}$ C age (BP) & Comments & Horizon \\
\hline QRM 2079/3, Gd-12816 & $9870 \pm 95$ & In accordance with archaeological data & 3 \\
QRM 2077/10, Gd-12820 & $9880 \pm 80$ & In accordance with archaeological data & 3 \\
QRM 1420, Gd-16285 & $10,050 \pm 140$ & In accordance with archaeological data & 3 \\
QRM 1248, Gd-30070 & $10,260 \pm 130$ & $\begin{array}{l}\text { Date too early for this structure, which seems to } \\
\text { belong to later part of H3 }\end{array}$ & 3 \\
& & \\
QRM 1268, Gd-15680 & $10,350 \pm 150$ & Date too early for this grave & 3 \\
QRM 1014/17, Gd-15488 & $10,590 \pm 150$ & Date too early for this horizon of occupation \\
QRM 2055/4, Gd-12798 & $10,900 \pm 110$ & $\begin{array}{l}\text { Date too early; aberration (soil taken from deeper } \\
\text { layers near PPNA settlement?) }\end{array}$ \\
& & 3 \\
QRM 904/16, Gd-30017 & $9690 \pm 100$ & In accordance with archaeological data & 4
\end{tabular}

\section{Horizons}

Based on the archaeological investigations, all samples were assigned to 5 horizons, $\mathrm{H} 0-\mathrm{H} 4$ (Table 2). Figure 2 presents the distribution of calendar dates divided into various horizons. Aberrant dates and dates with large uncertainties were excluded to establish the duration of the individual horizons. Aberrations resulting from using older material disturbed by newer constructions, bioturbation caused by moles and other animal activity, the long growth of some of the trees used for wood by prehistoric inhabitants at Qaramel, have led to an excessively cautious approach by archaeologists when attributing particular occupation levels to horizons based on archaeological information. As discussed above, comparison with the ${ }^{14} \mathrm{C}$ dating results came later. What is important from the archaeological point of view is that all ${ }^{14} \mathrm{C}$ dates a form a curve that confirms Mazurowski's scheme of permanent and evolutionary evolution of the Qaramelian culture built on the archaeological criteria. Some disagreements between archaeological classification of a structure into concrete horizons and ${ }^{14} \mathrm{C}$ dates could be explained by the problems listed above (Table 1). It is necessary to say, however, that many of these aberrant ${ }^{14} \mathrm{C}$ dates are pretty good for general dating of a whole site. The $95.4 \%$ confidence intervals obtained from the summed probability distribution provide information about the boundaries of each horizon (Table 2, Figure 3).

Table 2 Time span of horizons $\mathrm{H} 0-\mathrm{H} 4$.

\begin{tabular}{lcc}
\hline Horizon & $\begin{array}{l}\text { Beginning } \\
\text { (yr BC) }\end{array}$ & $\begin{array}{l}\text { End } \\
\text { (yr BC) }\end{array}$ \\
\hline H0 & 16,890 & 10,980 \\
H1 & 10,890 & 9670 \\
H2 & 10,670 & 9250 \\
H3 & 9820 & 8710 \\
H4 & 9310 & 8780 \\
\hline
\end{tabular}

All horizons are characterized in detail in Mazurowski and Kanjou (2009), whose recent book presents the archaeological results of excavations at Qaramel from 1999-2007. Here, only the most important elements typical for each horizon are given.

Horizon H0 (16,890-10,980 cal BC) contains only a fragmentary known level of occupation 0 with remains of the Early Epipaleolithic occupation described earlier.

Horizon H1 (10,890-9670 cal BC) is represented by levels of occupation I-III with the remains of the Protoneolithic stadium, named by Mazurowski as "Proto-Qaramelian." They have been desig- 
Figure 2 Results of calibration for individual horizons. Aberrant dates and dates with large laboratory uncertainty (see Table 1) were excluded. The summed probability distribution for a particular horizon is marked at the top of each group.

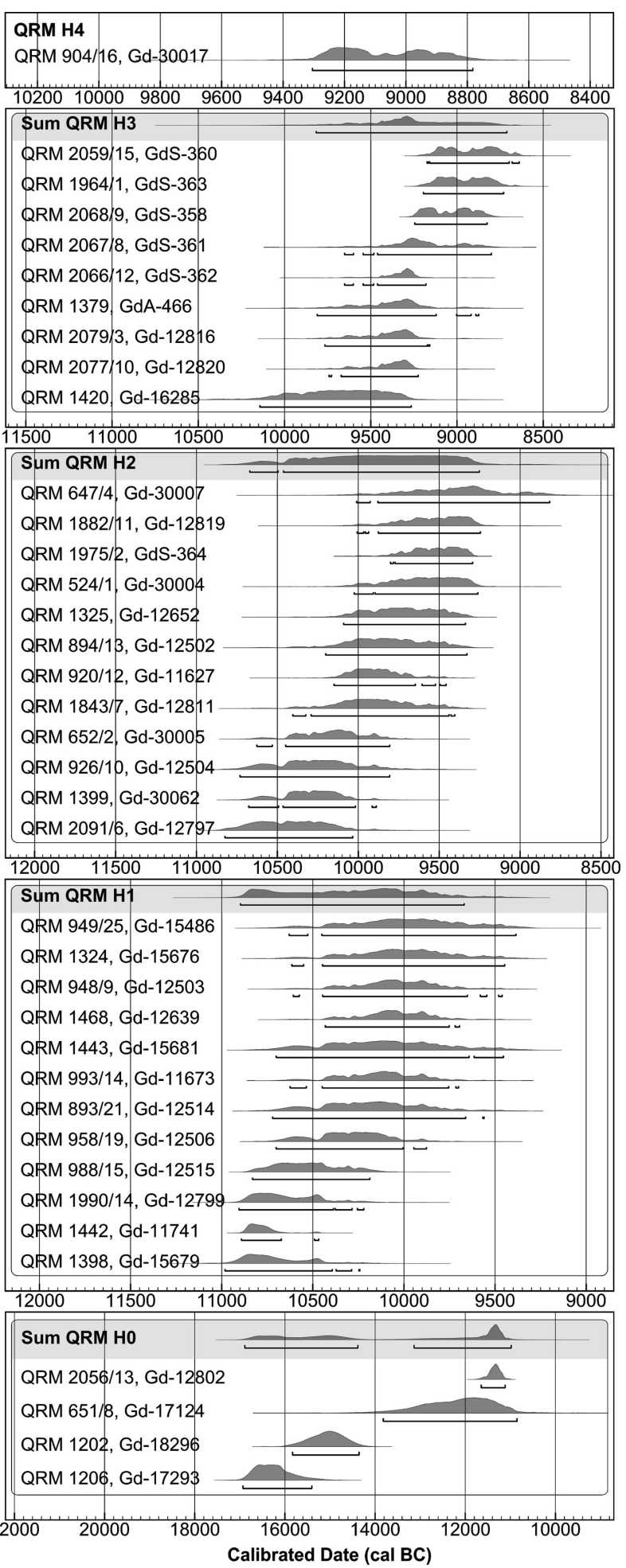




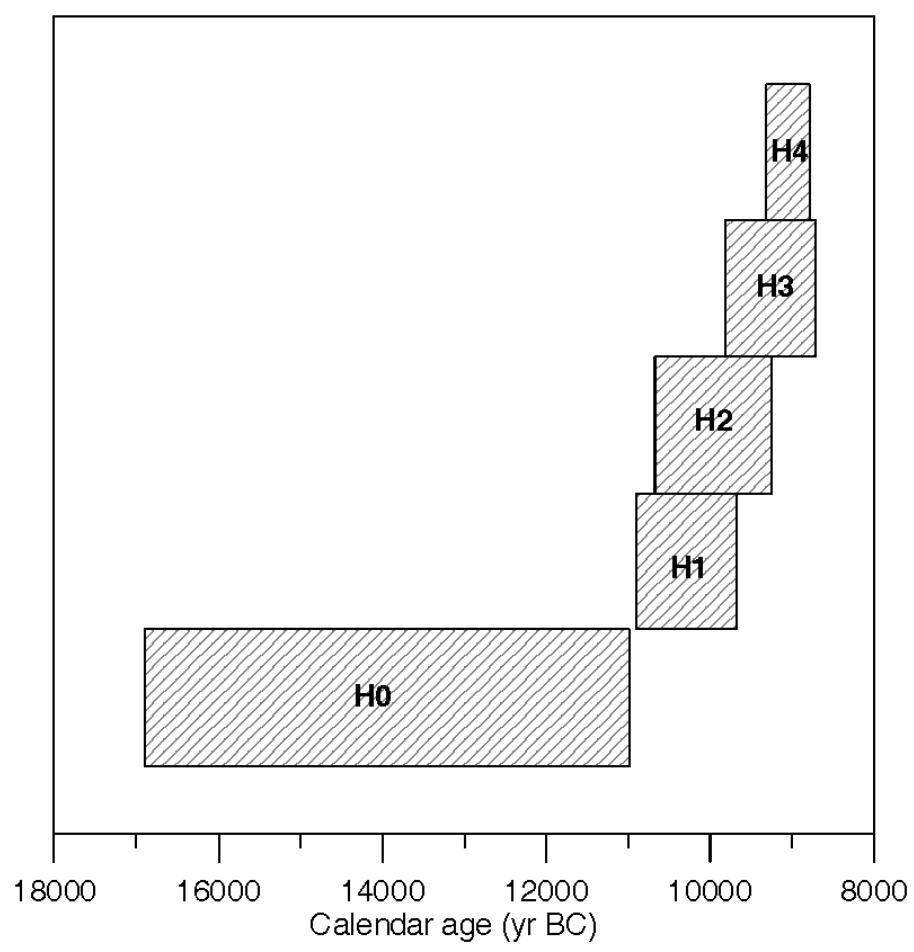

Figure 3 Time span of horizons H0-H4

nated to this new taxonomic unit due to the chipped stone industry, demonstrating many important differences from the Kebarian and Natufian traditions. For the Proto-Qaramelian, the blade technique is dominant, taking advantage of regular-size unipolar cores and a very early and exclusive presence of El-Khiam and Qaramel points (common in Natufian and Khiamien), combined with very rare microliths. The stratigraphy of the site and ${ }^{14} \mathrm{C}$ dating have shown that El-Khiam points were there much earlier than in the southern Levant and Middle Euphrates regions. Importantly, ElKhiam points were discovered in Qaramel with completely different chipped stone industry complex compared to the southern Levant and Middle Euphrates areas. The occurrence of aboveground houses is typical in horizon $\mathrm{H} 1$, serving either as shelters or houses (2-3 m diameter), constructed in the "skeleton technique" (mid-sized stone pebbles partly dug into ground and blocks of mud placed above shaped manually). These houses are occasionally accompanied by partly subterranean constructions. Also, 3 of the oldest circular towers (V-III) belong to this horizon. They perhaps foremost served as a cult and assembly place (shrine/common house).

Horizon H2 (10,670-9250 cal BC) contains levels of occupation IV-VII, which represent attributes typical of the Early Pre-Pottery Neolithic A in the Levant. It is also the beginning of the Qaramelian cultural tradition, which shall continue until the end of settlement in horizon H4. There is no break between the Proto-Qaramelian and Qaramelian; the transition is very smooth and without rapid changes in the architecture or in the chipped stone industry. Still, unipolar core technology is dominates, but the bipolar technique increases to $82 \%$ in horizon $\mathrm{H} 4$. Together with this process, dominated El-Khiam and Qaramelian points are dominant but gradually accompanied by Jordan Valley, Helwan, and sporadically by Nevala Çori points. Herminettes, Mureybet, Sheikh Hassan, and Jerf el-Ahmar points are absent. Only in horizon H4 have 4 Mureybet points ( 2 on the surface) been found. In the late horizon $\mathrm{H} 2$, the first single Netive Hagdud and Gilgal truncations were discovered. 
Both forms of truncations increase in frequency in the layers of horizons $\mathrm{H} 3$ and $\mathrm{H} 4$. Until now, the Qaramelian has also not presented any evidence of typical navy-core and hitting flint technology with only a several cores prepared recalling proto-navy core technology. Also, the most monumental circular tower (II) was built in horizon $\mathrm{H} 2$.

Horizon H3 (9820-8710 cal BC) covers layers and structures from occupation levels VIII-XII typical for the Qaramelian culture, corresponding to the Middle PPNA in the Levant. This is the time of apogeal development. In this horizon, single-room circular or oval buildings frequently coexisted with multiroom forms and initial subrectangular rooms. Many houses become larger and they are built in pisé/tauf technology, as well as mixed ones (levels of mud and pebbles) and with the use of the limestone. In horizon H3, on the ruins of tower II, the youngest tower (I) was built. To this horizon also belong 2 very exceptional structures. The first is a monumental elongated building $(10 \times$ $5 \mathrm{~m}$ ) divided into 3 different shapes and arrangements. It was used as a shrine/common house. Its special function is confirmed by its inside arrangement, and it is nearest to 27 human and 4 animal graves and 2 spectacular foundation deposits: the imported massive flint Jericho type celt with surface retouch on both sides and a complete female figurine made of white soft limestone. The second unique building was situated northeast of tower I. In the center of this circular building, there was a large, stone stylization of auroch bucrania. Four real auroch bucrania were situated in a round pit in the floor surrounded by pebbles, located within the arch of one these stylized horns. The ritual function of the described house is confirmed by a lack of evidence for everyday activity in the interior.

Horizon H4 (9310-8780 cal BC) represents the final stage in the development of the Qaramel settlement, corresponding to the beginning of the Late PPNA in the Levant, that is, the beginning of the Jerf el-Ahmar settlement and the end of IIIA and beginning of IIIB in Mureybet. Until now, only occupation level XIII has been assigned to H4. Remnants of horizon H4 have been discovered only in the southernmost trenches, which allows for the possibility that in the final moment of development the PPNA village changed its range more to the south and west. Knowledge of architecture from horizon $\mathrm{H} 4$ is unsatisfactory because the XIII level of occupation was in some trenches very heavily destroyed by younger occupations. It is possible to say, however, that in addition to the form of houses well known from $\mathrm{H} 3$, also 2 rectangular buildings made in pisé/ tauf technology have been found in $\mathrm{H} 4$. One of them is in multicell form, with the round room being attached to a slightly older unit. Most likely, the same situation took place in the other case. To horizon $\mathrm{H} 4$ also belongs the simple, oval and irregular $(3.20 \times 2.60 \mathrm{~m})$ platform with a hearth at the center. It is also a very possible that after the end of occupation in horizon $\mathrm{H} 4$, inhabitants of Qaramel created a new settlement situated about $1.5 \mathrm{~km}$ to the southwest on the same terrace of the Nahar Qoueig River, beside the modern village of Tleilath. On the surface of this open settlement, flint objects belonging to the PPNB stadium have been found.

\section{CONCLUSIONS}

Excavations at the settlement Tell Qaramel were concentrated on remnants of the early stages of the Pre-Pottery Neolithic period-a time of transformation from a hunting-gathering economy to the domestication of plants and animals. ${ }^{14} \mathrm{C}$ dating results show occupation and evolution of the settlement from the early stages of the Pre-Pottery Neolithic period, which covers 10,900-8800 BC.

Discoveries at Qaramel are very important for scientific research in the area because they show a permanent evolution of transformation to traditional Neolithic culture by a long process that extended over more than a thousand years. Moreover, Qaramel is located in a new, completely unknown region (center) of the so-called "primary Neolithization." Mazurowski (2009a) named its culture "Qaramelian" and its Protoneolithic stage, "Proto-Qaramelian." Its urbanity, architecture, 
economy, and material culture represent many differences when compared to the sites known from Middle Euphratus (Mellart 1975; Cauvin 1997; Stordeur 2000), Anatolia (Özdogan and Basgelen 1999; Schmidt 2006), southern Levant (Bar-Yosef 1991; Bar-Yosef and Bar-Yosef-Mayer 2002; Goring-Morris and Kuijt 2002), northern Mesopotamia and Chusistan (Braidwood et al. 1983; Kozlowski and Aurenche 2005; Kozlowski 2002). This exposure to the north, and to an earlier unknown cultural tradition of Pre-Pottery Neolithic in the Levant, existed alongside such traditions as the Sultanien in the south and Mureybetien in the Middle Euphratus region. The results of the ${ }^{14} \mathrm{C}$ chronology confirm Mazurowski's opinion that the Proto-Qaramelian and than Qaramelian cultural tradition are the result of the formation of a new center of primary Neolithization from a hitherto unknown local Epipaleolithic culture-different from the Natufian, in the same time as in several other regions of the Near East (Bar-Yosef and Kra 1994). Very good environmental conditions in this new center allowed its inhabitants to form a highly developed "PPNA culture," which was based on the model of economy typical for a very specialized gatherers and hunters, without the need for domestication of plants and animals. Thus, at Qaramel we have the same situation as at Göbekli Tepe in the Taurus region (Schmidt 2006). Both sites give a new background to the methodological discussion about models of transformation into the classic Neolithic culture.

\section{ACKNOWLEDGMENTS}

The project is a joint undertaking of the Polish Centre of Mediterranean Archaeology, Warsaw University and Direction General for Antiquities and Museums of Syria. Fieldwork and laboratory analyses also have the substantial support from Her Excellency Rector of the Warsaw University and the Institute of Archaeology, Warsaw University. ${ }^{14} \mathrm{C}$ analyses were performed within the Silesian University of Technology BK-234/RMF-1/2007 grant (Gliwice, Poland).

\section{REFERENCES}

Aurenche O, Kozlowski SK. 1999. La naissance du Neolithique au Proche Orient ou le paradis perdu. Paris: Editions Errance.

Bar-Yosef O. 1991. The Early Neolithic of the Levant: recent advances. The Review of Archaeology 12:1-18.

Bar-Yosef O, Bar-Yosef-Mayer DE. 2002. Early Neolithic tribes in the Levant. In: Parkinson WA, editor. The Archaeology of Tribal Societies. Ann Arbor, MI, USA: International Monographs in Prehistory. p 34071.

Bar-Yosef O, Kra R, editors. 1994. Late Quaternary Chronology and Paleoenvironments of the Eastern Mediterranean. Tucson: Radiocarbon.

Braidwood LS, Braidwood RJ, Howe B, Reed CA, Watson PJ, editors. 1983. Prehistoric Archaeology along the Zagros Flanks. Chicago: Oriental Institute of the University of Chicago.

Bronk Ramsey C. 1995. Radiocarbon calibration and analysis of stratigraphy: the OxCal program. Radiocarbon 37(2):425-30.

Bronk Ramsey C. 2001. Development of the radiocarbon calibration program. Radiocarbon 43(2A):355-63.

Buck CE, Kenworthy JB, Litton CD, Smith AFM. 1991. Combining archaeological and radiocarbon information: a Bayesian approach to calibration. Antiquity 65(249):808-21.
Cauvin J. 1997. Naissance des divinités, naissance de l'agriculture: La Révolution des symboles au Néolithique (Reliure inconnue). Paris: CNRS.

Goslar T, Czernik J. 2000. Sample preparation in the Gliwice Radiocarbon Laboratory for AMS ${ }^{14} \mathrm{C}$ dating. Geochronometria 18:1-8.

Goring-Morris AN, Kuijt I. 2002. Foraging, farming and social complexity in the Pre-Pottery Neolithic of the Southern Levant. A review and synthesis. Journal of World Prehistory 16(4):361-440.

Grezak A. 2009. Animal bone remains from Tell Qaramel. In: Mazurowski RF, Kanjou Y, editors. Documents D'archeologie Syrienne. Damascus: DGAM. p 96-103.

Heinemeier J, Jungner H, Lindroos A, Ringbom A, von Konow T, Rud N. 1997. AMS ${ }^{14} \mathrm{C}$ dating of lime mortar. Nuclear Instruments and Methods in Physics Research B 123(1-4):487-95.

Hodgins GWL, Vonarx AJ, Bachand B. 2006. AMS radiocarbon dating of protoclassic Maya lime plasters from Aguateca, Guatemala. In: Proceedings of the 34th International Symposium on Archaeometry. Zaragoza: Institución Fernando el Católico. p 73-8.

Kozlowski SK, editor. 1998. M'lefaat, Early Neolithic site in northern Iraq. Cahiers de l'Euphrate 8:179273. 
Kozlowski SK. 1999. The Eastern Wing of the Fertile Crescent. Late Prehistory of Greater Mesopotamian Lithic Industries. BAR International Series 760. Oxford: Archaeopress.

Kozlowski SK. 2002. Nemrik. An Aceramic Village in Northern Iraq. Warsaw: Agade.

Kozlowski SK, Aurenche O. 2005. Territories, Boundries and Cultures in the Neolithic Near East. BAR International Series 1362. Oxford: Archaeopress.

Mazurowski RF. 2000. Tell Qaramel. Preliminary report on the first season, 1999. Warsaw University. Polish Archaeology in the Mediterranean XI:315-30.

Mazurowski RF. 2003. Tell Qaramel. Excavations 2002. Warsaw University. Polish Archaeology in the Mediterranean XIV:315-30.

Mazurowski RF. 2004. Tell Qaramel. Excavations 2003. Warsaw University. Polish Archaeology in the Mediterranean XV:355-70.

Mazurowski RF. 2005. Tell Qaramel. Excavations 2004. Warsaw University. Polish Archaeology in the Mediterranean XVI:497-510.

Mazurowski RF. 2006. Tell Qaramel. Excavations 2005. Warsaw University. Polish Archaeology in the Mediterranean XVII:483-500.

Mazurowski RF. 2009a. Tell Qaramel. General remarks about the site and excavations. In: Mazurowski RF, Kanjou Y, editors. Documents D'archeologie Syrienne. Damascus: DGAM. p 9-27.

Mazurowski RF. 2009b. Ground and pecked stone industry and objects of art from Aceramic settlement Tell Qaramel. In: Mazurowski RF, Kanjou Y, editors. Documents $D$ 'archeologie Syrienne. Damascus: DGAM. p 59-74.

Mazurowski RF, Jamous B. 2001. Tell Qaramel. Excavations 2000. Warsaw University. Polish Archaeology in the Mediterranean XII:327-43.

Mazurowski RF, Kanjou Y, editors. 2009. Documents $D$ 'archeologie Syrienne. Damascus: DGAM. In English, French, and Arabic editions.

Mazurowski RF, Yartah T. 2002. Tell Qaramel. Excavations 2001. Warsaw University. Polish Archaeology in the Mediterranean XIII:295-307.

Mazurowski RF, Bialowarczuk M, Januszek K. 2009. Architecture of Tell Qaramel. In: Mazurowski RF, Kanjou Y, editors. Documents D'archeologie Syrienne. Damascus: DGAM. p 28-49.

Mellaart J. 1975. The Neolithic of the Near East. London: Thames \& Hudson.

Michalska Nawrocka D, Michczyńska DJ, Pazdur A, Czernik J. 2007. Radiocarbon chronology of the ancient settlement in the Golan Heights area, Israel. Radiocarbon 49(2):625-37.
Nawrocka D, Michniewicz J, Pawlyta J, Pazdur A. 2005. Application of radiocarbon method for dating of lime mortars. Geochronometria 24:109-16.

Özdogan M, Basgelen N, editors. 1999. Neolithic in Turkey, Arkeoloji ve Sanat Yayinlari. Istanbul.

Pazdur A, Pazdur MF. 1986. Aparatura pomiarowa Laboratorium ${ }^{14} \mathrm{C}$ w Gliwicach. Doświadczenia konstrukcyjne i eksploatacyjne [The measuring equipment of the Gliwice Radiocarbon Laboratory. Experience gathered in the construction and exploatation]. Zeszyty Naukowe Politechniki Ślqskiej, Seria MatematykaFizyka 46, Geochronometria 1:55-69. In Polish.

Pazdur A, Michczyński A, Pawlyta J, Spahiu P. 2000. Comparison of the radiocarbon dating methods used in the Gliwice Radiocarbon Laboratory. Geochronometria 18:9-13.

Pazdur A, Fogtman M, Michczyński A, Pawlyta J. 2003. Precision of ${ }^{14} \mathrm{C}$ dating in Gliwice Radiocarbon Laboratory. FIRI Programme. Geochronometria 22:27-40.

Piotrowska N, Goslar T. 2002. Preparation of bone samples the Gliwice Radiocarbon Laboratory for AMS radiocarbon dating. Isotopes in Environmental and Health Studies 38(4):267-75.

Schmidt K. 2006. Sie bauten den ersten Tempel. Das rätselhafte Heilighthum der Steinzeitjäger. Die archäeologische Entdecklung am Göbekli Tepe. Munich: C.H. Beck.

Sonninen E, Jungner H. 2001. An improvement in preparation of mortar for radiocarbon dating. Radiocarbon 43(2A):271-3.

Stordeur D. 2000. New discoveries in architecture and symbolism at Jerf el Ahmar, Syria (1997-1999). NeoLithics 1:1-4.

Stuiver M, Polach HA. 1977. Discussion: reporting of ${ }^{14} \mathrm{C}$ data. Radiocarbon 19(3):355-63.

Van Strydonck M, Dupas M, Dauchot-Dehon M, Pachiaudi C, Marechal J. 1986. The influence of contaminating (fossil) carbonate and the variations of $\delta^{13} \mathrm{C}$ in mortar dating. Radiocarbon 28(2A):702-10.

Willcox G. 2005. The distribution, natural habitats and availability of wild cereals in relation to their domestication in the Near East: multiple events, multiple centres. Vegetation History and Archaeobotany 14(4): $534-41$.

Willcox G, Herveux L. 2009. Late Pleistocene/Early Holocene charred plant remains from Tell Qaramel: a preliminary report. Mazurowski RF, Kanjou Y, editors. Documents D'archeologie Syrienne. Damascus: DGAM. p 104-12.

Willcox G, Fornite S, Herveux LH. 2008. Early Holocene cultivation before domestication in northern Syria. Vegetation History and Archaeobotany 17:313-25. 